\title{
Morphologic aspects of the genital tract from Nellore cows undergoing gynecological screening to insertion in the fixed-time artificial insemination (TAI) program
}

\author{
MELLO, R. R. C. ${ }^{1}$, MELLO M. R. B. ${ }^{2}$, ABIDU-FIGUEIREDO, M. $^{3 *}$, \\ SCHERER, P. O. ${ }^{3}$ and PALHANO, H. B. ${ }^{3}$
}

\author{
${ }^{1}$ Postgraduate Student of Animal Production Course, Institute of Animal Science, Rio de Janeiro Federal Rural \\ University - UFRRJ, Rodovia BR 465, Km 7, CEP 23890-000, Seropédica, RJ, Brasil \\ ${ }^{2}$ Department of Animal Reproduction and Evaluation, Institute of Animal Science, Rio de Janeiro Federal Rural \\ University - UFRRJ, Rodovia BR 465, Km 7, CEP 23890-000, Seropédica, RJ, Brasil \\ ${ }^{3}$ Animal Biology Department, Institute of Biology - IB, Rio de Janeiro Federal Rural University - UFRRJ, \\ Rodovia BR 465, Km 7, CEP 23890-000, Seropédica, RJ, Brasil \\ *E-mail: marceloabidu@gmail.com
}

\begin{abstract}
Introduction: This study aimed to evaluate the morphology of the genital tract from 98 Nellore cows by rectal palpation and combine them with the functional aspects for inclusion in a fixed-time artificial insemination (TAI) program. Methods: Were evaluated the ovaries, cervix and vulva, as well as the body condition score (BCS scale 1-5). Results: In relation to the ovaries, there were palpable structures found in 51 (17 CL and $34 \mathrm{FL}$ ) in the rights ovarian and 37 palpable structures (06 CL and $31 \mathrm{FL}$ ) in the left ovary. Asymmetry was found in $17.3 \%$ and uterine cervicitis in $20.4 \%$ of examined females. Changes were noted in vulva in $51.0 \%$ (40 to 10 papules and hyperemia) and the average of BCS was 3.15. On the basis of morphological aspects founded, 29 females with an average of BCS 2.7 and 01 with metritis were excluded and 07 (BCS-3, 5) inseminated immediately after the exam, with 61 included in the TAI program. These data support the conclusion that of all ovulations occurred, characterized by the presence of CL, most occurred in the right ovary $(73.9 \%)$. The prevalence rate $(51 \%)$ of vulvar aspects found, indicate a need for research of reproductive diseases in their flock. Conclusion: The BCS may impacts on the cyclicity and in the pregnancy rate of females included in the program.
\end{abstract}

Keywords: morphological aspects, Nellore cows, TAI.

\section{Introduction}

The growing demand of food production in the world for the human population has indicated a strong impact on the market of animal products in Brazil, putting the emphasis on production and marketing of beef. Thus, the dynamics of the national livestock producers requires an improvement in their technical procedures, aiming to increase reproductive efficiency and production of their herds.

In this context, the use of fixed-time artificial insemination (TAI) as a management tool for improving reproductive indicators, has been progressively increasing, which requires training of the employers in the farms as well as careful technical analysis of the females to be included in the program.

In extensive systems of cattle cutting, both in Brazil and the U.S., there is a high rate of anestrus $(50 \%)$ at the beginning of the breeding season, that associated with failures in estrus detecting, determine a low reproductive performance of herds (LUCY, BILLINGS, BUTLER et al., 2001; GASSER, BEHLKE, BURKE et al., 2003; MADUREIRA and PIMENTEL, 2005), and low rate of enjoyment from them.

Fonseca (1991) reported the negative effect of breastfeeding on the estrous cycle in beef cows, determining postpartum anestrus due to the inhibition of $\mathrm{GnRH}$ secretion by endogenous opioids (enkephalins, endorphins and dynorphins). This hypothesis is based on studies by Malveen (1984), Whisnant, Kiser and Thompson (1986) and Armstrong and Johnson (1989), who reported a stronger effect when cows have an unfavorable body condition (BC) during the puppy birth.

So many studies (RYAN, SPOON, GRIFFITH et al., 1994; BISHOP, WETTEMANN, and SPICER, 1994; LUCY, 2003; ARMSTRONG, GONG and WEBB, 2003; MADUREIRA and PIMENTEL, 2005; MENEGHETTI and VASCONCELLOS, 2008) are being conducted in order to correlate the $\mathrm{BC}$ with the reproductive physiology as well as the productive and reproductive rates (MCMANUS, SAUERESSIG, FALCÃO et al., 2002; VIEIRA, LOBATO, TORRES JUNIOR et al., 2005), so you can make use of many strategies aimed at minimizing the economic losses resulting from the negative impact caused by unfavorable body condition of cows.

Anderson et al. (1991) and Ferreira, Lopes and Dantas (1999) reported the importance of screening for female cows by rectal palpation for assessment of reproductive characteristics such as size of the uterine horn, uterine tone, size of the ovaries, the presence of ovarian structures as the corpus luteum (CL) and follicles (FL). According to these authors, this selection may be useful for predicting the 
fertility of these females, which may contribute to better results in TAI programs.

In this regard, Ribeiro Filho, Portela, Chalhoub et al. (2002) considered the possibility that these reproductive characteristics influence the results of pregnancy in TAI programs with zebu cattle. Thus, through the screening, there were evaluated the influence of the presence or absence of CL, uterine tone and parity order on the pregnancy rate of Zebu cattle in three protocols for estrus synchronization and ovulation. They concluded that the prior evaluation of reproductive characteristics had a positively influence in the pregnancy rate between the synchronization protocols presented.

In a study of prepubertal and postpubertal female cows correlation in morphometric ovary at different reproductive stages, Nascimento, Pinheiro, Sales et al. (2003) evaluated in the laboratory, 200 ovaries obtained from slaughterhouses and found that the size of these animals differed between prepubertal and postpubertal. There was no difference in the ovaries size among animals with luteal and cyclical ovarian activity and pregnant animals, but CL were higher and largest follicle diameter, smaller. The parameters were affected by the estrous cycle and the gestation period. In animals with estrous cycles, we observed a significant correlation between the size of the ovary and CL. The authors concluded that the ovarian morphologic characteristics vary with the reproductive stages, can be used as a parameter for it clinical and functional evaluation.

The characterization of CL, for example, provides important information about the reproductive state of the female bovine and enables the adaptation of procedures for manipulation or synchronization of estrus cycles (VIANA, FERREIRA, SÁ et al., 1999), being the increase in volume which provides CL to the ovary where it is present, an efficient method to estimate the total luteal mass by rectal palpation (FERNANDES and VELÁSQUEZ, 1997).

Neves, Marques Junior, Santana et al. (2002) found the frequency balanced percentage of CL, and $48.8 \%$ for the right and $51.2 \%$ for the left in the ovaries of zebu females, collected at the slaughterhouse, however, Chacur, Valentim, Martinez et al. (2006) report a higher frequency of LC to the left ovary $(65.5 \%)$ compared to the right ovary $(34.5 \%)$, concluding that the morphological characteristics of the ovaries, vary with the estrous cycle and may be used as a parameter in it clinical and functional assessment, but the presence of CL of the type included in zebu cows suggests that rectal palpation of ovarian structures is not always effective in predicting ovarian luteal cyclic activity.

Through comparative morphological study of ovaries from cows and heifers of Nellore, Monteiro et al. (2008) reported a rate of $85 \%$ of CL in the ovaries left $60 \%$ for cows and heifers, showing also the highest frequency of ovulation in these ovaries, there was, however, statistically significant difference for the frequency of mature follicles between right and left ovaries and between cows and heifers.

In relation to the uterus, diseases such as metritis, increased tone and determine asymmetry of the uterine horns (PALHANO, JESUS, TRÉS et al., 2008), detectable rectal palpation, a loss of productivity to lengthen the period of service (PS) and calving interval (CI) contributing to failures in TAI programs when the screening of reproductive females is not performed.
Likewise, lesion vesicles such as vagina, vulva, pustules, edema and hyperemia which characterize the vulvovaginitis, may be related to infection by bovine herpesvirus type 1 (IBR) and Mycoplasma infections (TAKIUCHI, ALFIERI and ALFIERI, 2001; NASCIMENTO, D'ANGELIS, NASCIMENTO et al., 2005) that can directly interfere with the reproductive and productive indicators and should therefore be properly managed and monitored proactively.

Thus, this study aimed to describe the morphologic features of the reproductive tract of Nellore cows submitted to gynecological screening prior to TAI program, from those seeking to establish the criteria for inclusion of arrays in the program and evaluate the results expressed as total pregnancy rate.

\section{Materials and Methods}

Between the months of November 2009 and May 2010 it were evaluated 98 lactating and multiparous females of Nellore aged between 5 and 9 years old from a commercial herd of about 500 headquarters, located in the district of Iguaba Grande Lakes Region in the State of Rio de Janeiro, Brazil. All the animals were kept on pasture in an extensive system of paddock seasonal rotating made under the technical guidance, mineral supplementation, free access to water all year long and supplementation with protein salt in the dry season.

The breeding herd system was the result of the artificial insemination with observation of heat and rapasse with bulls, however, 98 multiparous females were randomly selected to participate and be included in a program of fixed-time artificial insemination (TAI). The reproductive management, for all animals was performed within a breeding season (BS) between the months of November and February, all the bulls being removed on the last day of BS.

Regarding to the sanitary handling, all the animals were vaccinated against foot and mouth disease following the calendar set by the Ministry of Agriculture, Livestock and Supply (MAPA). All the females aged between three and eight months old were vaccinated against brucellosis with the vaccine strain B-19. All the females of reproductive age were vaccinated against leptospirosis. The clostridial vaccination was performed in all animals aged between three and five months old being scheduled for the reinforcement 12 and 24 months old. The tests for brucellosis and tuberculosis were performed once a year.

Have not been conducted andrological examinations to sperm analysis examinations or tests for the diagnosis of reproductive diseases as bovine trichomoniasis and genital campylobacteriosis in bulls pass.

The 98 selected females for the study were submitted to a visual evaluation of the body condition (BC), whose body condition score (BCS) ranged on a scale of 1 to 5 , where 1 corresponds to an animal very thin and 5 an animal fat. After evaluation of the BCS, these females were submitted to a gynecological screening by semiological examination by rectal palpation, evaluating the cyclicality (presence or absence of ovarian structures such as follicles and corpus luteum: FL-CL), and the occurrence of acquired or congenital disorders from the genital tract (vaginitis, cervicitis, metritis, subclinical endometritis, follicular cyst, ovarian hypoplasia and tortuous cervix unilateral total). 
We sought to evaluate the possible impact of $\mathrm{BC}$ on the cyclicality through the ovarian aspects.

After realization of the whole screening process, involving evaluation of BCS and gynecological examination, it were stratified females who participated in the TAI program. As exclusion criteria, we used the BCS, which excluded females with a score $<2.5$, females with congenital and / or acquired genital tract that required treatment or discard, independent of the BCS, which eventually were pregnant females and detected females in estrus during the examination, and were immediately artificially inseminated.

As a protocol for synchronization of estrus TAI was used $2.0 \mathrm{mg}$ of oestradiol benzoate $\left(\right.$ Gonadiol $^{\circledR}$ ) or intramuscularly (IM) and the introduction of bovine intravaginal device $\left(\mathrm{DIB}^{\circledR}\right)$ containing $1.0 \mathrm{~g}$ of progesterone in D0, D8 DIB was removed and applied $250 \mathrm{mcg}$ of cloprostenol $\left(\mathrm{Ciosin}^{\circledR}\right)$ and 300 IU eCG (Folligon ${ }^{\circledR}$ ) intramuscularly in D9 was applied $1.0 \mathrm{mg}$ of estradiol benzoate, and artificial insemination held in D10 (16-18 hours after administration of oestradiol benzoate).

After completion of screening and gynecological TAI program, all inseminated cows were submitted to the bulls coverage as transfer and evaluated results were expressed as rate design the protocol and total pregnancy rate (TAI + bull)

\section{Results and Discussion}

Of the 98 randomly selected cows from the herd home, 61 were considered eligible to participate in the TAI program, by presenting BCS $\geq 2.5$ and absence of genital lesions that could impair ovulation and conception. Depending on the morphological aspects found, 29 females with an average of 2.7 BCS with acquired lesions (cervicitis associated with uterine asymmetry) were excluded. Seven females were inseminated immediately to gynecological exam for showing signs of heat during the same, and one female was excluded

Table 1. Morphological characteristics of the ovaries, according to structures found on their surfaces, by rectal palpation.

\begin{tabular}{lcc}
\hline \multicolumn{1}{c}{ Findings } & RO & LO \\
\hline CL & 17 & 06 \\
FL & 34 & 31 \\
L & 31 & 44 \\
SHS & 16 & 17 \\
Total palpable strutctures & 51 & 37 \\
Total no palpable structures & 47 & 61 \\
General total & 98 & 98
\end{tabular}

CL, corpus luteum, FL: follicle; L: smooth (no structures) SHS: small hard and smooth. for having the presence of asymmetric uterine with purulent vulvar discharge, featuring a clinical picture of acute metritis.

With respect to the ovaries, it were found palpable structures in 51 (17 CL and $34 \mathrm{FL}$ ) and no palpable structure in 47 of ovarian rights and 37 palpable structures (06 CL and $31 \mathrm{FL}$ ) with no palpable structures 61 in the left ovary (Table 1$)$, statistically significant difference $(\mathrm{P}<0.05)$ by chi-square between the number of CL found in the right and left ovaries, which is consistent with the data of Monteiro et al. (2008) and Chacur, Valentim, Martinez et al. (2006) those who demonstrated that a higher percentage of ovulation in the right ovary, but differs, the results found by Neves, Marques Junior, Santana et al. (2002) that found that a balanced percentage frequency of CL. There was no statistically significant difference $(P>0.05)$ by the same test, between the number of follicles in the ovaries left and right, corroborating the data from Monteiro et al. (2008) who also found no difference in the number of follicles found in both ovaries.

Asymmetry was observed in $17.3 \%$ and uterine cervicitis in $20.4 \%$ of females examined, with one of the females showing clinical signs of acute metritis when presenting purulent vulvar discharge associated with asymmetry of the uterine horns and increased uterine tone, as described by Palhano, Jesus, Trés et al. (2008). It was found alterations of the vulva in $51.0 \%$ being 40 to 10 with papules and hyperemia (Table 2), and these lesions of the vagina and vulva that characterize IPV related to animals suffering from herpes virus I (IBR) and by Mycoplasma, as reported by Takiuchi, Alfieri and Alfieri (2001) and Nascimento, D'Angelis, Nascimento et al. (2005), however, in this study, no specific diagnostic tests were performed for these diseases.

With respect to the BCS and the cyclicity, 20 females with a score $>2<2.5$ had their ovaries inactive, none were detected palpable structure (CL or FL) on their surfaces (Table 3 ), and $50 \%(10: 20)$ of these animals had small hard and smooth ovaries (SHS) can be observed so that the impact of BC on the cyclicity according to data presented by Ryan, Spoon, Griffith et al. (1994), Bishop, Wettemann and Spicer (1994), Lucy (2003), Armstrong, Gong and Webb (2003), Madureira and Pimentel (2005) and Meneghetti and Vasconcellos (2008) as well as the effect of feeding, which according to Whisnant, Kiser and Thompson (1986), Malveen (1984), Armstrong and Johnson (1989) and Fonseca (1991), contributes to low productivity of livestock (MCMANUS, SAUERESSIG, FALCÃO et al., 2002; VIEIRA, LOBATO, TORRES JUNIOR et al., 2005). 71 females with BCS $>2.5$ and seven $\mathrm{BCS}=2.5$, showed cyclicity FL and CL were detected on their surfaces.

The conception rate to the protocol and total pregnancy (TAI + bull) was $60.4 \%$ and $83.9 \%$, respectively, being

Table 2. Morphological characteristics of the uterus, cervix and vulva of cows, according to rectal palpation.

\begin{tabular}{lccccc}
\multicolumn{1}{c}{ Findings } & Uterus (UT) & Findings & Cervix (CX) & Findings & Vulva (VV) \\
\hline UT-S & 81 & CX - N & 78 & VV-N & 48 \\
UT-ASS-D & 10 & CX - E & 20 & VV-P & 40 \\
UT-ASS-E & 7 & & & VV-HP & 10 \\
Total & 98 & & 98 & & 98 \\
\hline
\end{tabular}

UT-S: uterus symmetrical; UT-ASS-D: uterus asymmetrical of the rights horn; UT-ASS-E: uterus asymmetric of the left horn; CX-N: normal cervix; CX-E: edema VV-N: normal vulva, VV-P: vulva with pustules or vesicles; VV-HP: vulva hyperemia. 
Table 3. Morphological features of acyclic ovaries of females, according to rectal palpation.

\begin{tabular}{|c|c|c|c|c|c|c|}
\hline BCS $(1-5)$ & $\begin{array}{c}\mathrm{n}^{\circ} \text { cows } \\
\text { SNP }\end{array}$ & $\begin{array}{c}\mathrm{n}^{\circ} \text { cows } \\
\text { RO and LO } \\
\text { SHS }\end{array}$ & $\begin{array}{c}\mathbf{n}^{\circ} \text { cows } \\
\text { RO - SHS } \\
\text { LO - SNP }\end{array}$ & $\begin{array}{c}\mathbf{n}^{\circ} \text { cows } \\
\text { RO - SNP } \\
\text { LO - SHS }\end{array}$ & $\begin{array}{c}\mathbf{n}^{\circ} \text { cows } \\
\text { RO - SNP } \\
\text { LO - SNP }\end{array}$ & $\begin{array}{l}\mathbf{n}^{\circ} \text { cows } \\
\text { TOTAL }\end{array}$ \\
\hline$>2 \leq 2,5$ & 20 & 10 & 2 & 2 & 6 & 20 \\
\hline
\end{tabular}

SNP-structures no palpable RO-right ovary, LO-left ovary; SHS: small hard and smooth.

considered very good second TAI data reported by Ayres, Martins, Ferreira et al. (2008) and Meneghetti, Sá Filho, Peres et al. (2009).

\section{Conclusions}

The anatomical aspects of the genital tract of evaluated cows allows to conclude that the morphological characteristics of the ovaries vary according to the phase of the estrous cycle and nutritional status, which can impact negatively on the cyclicity and can be used as a parameter for functional assessment prior to TAI programs.

The aspects of this study indicate that off all ovulation occurred, characterized by the presence of CL, most occur in the right ovary $(73.9 \%)$.

The realization of gynecological screening aimed at evaluation of morphofunctional aspects of the genital tract of cows Nelore for insertion in TAI programs, influences positively the overall pregnancy rate of those subject to the program and allows the exclusion of females do not fit, thus providing lower operating costs as well as productivity gains, and gain greater when the herd is presented free of diseases that interfere with reproduction.

The prevalence rate $(51 \%)$ found in the vulvar aspects, indicate the needs for research on diseases that interfere in the reproduction of their herd.

\section{References}

ANDERSON, KJ., LEFEVER, DG., BRINKS, JS. and ODDE, KG. The use of reproductive tract scoring in beef heifers. Agricultural Practice, 1991, vol. 12, p. 19-26.

ARMSTRONG, DG., GONG, JG. and WEBB, R. Interactions between nutrition and ovarian activity in cattle: physiological, cellular and molecular mechanisms. Reproduction. Supplement, 2003, vol. 61, p. 403-414. PMid:14635951.

ARMSTRONG, JD. and JOHNSON, HB. Agonistis of endogenous apioid peptides suprpress LH, and stimulate cortisol and growth hormone during the follicular phase in heifers. Journal of Endocrinology, 1989, vol. 121, p. 11-17. PMid:2541216. http:// dx.doi.org/10.1677/joe.0.1210011

AYRES, H., MARTINS, CM., FERREIRA, RM., MELLO, JM., DOMINGUEZ, JH., SOUZA, AH., VALENTIN, R., SANTOS, ICC. and BARUSELLI, PS. Effectin of timing of estradiol benzoate administration upon synchronization of ovulation in suckling nelore cows (Bos indicus) treated with a progesterone-realesing intravaginal device. Animal Reproduction Science, 2008, vol. 109, n. 1-4, p. 77-87. PMid:18242017. http://dx.doi.org/10.1016/j. anireprosci.2007.12.001

BISHOP, DK., WETTEMANN, RP. and SPICER, LJ. Body energy reserves influence the onset of luteal activity after early weaning of beef cows. Journal of Animal Science, 1994, vol. 72, n. 10, p. 27032708. PMid:7883630.

CHACUR, MGM., VALENTIM, NC., MARTINEZ, AIS., TOSTES, RA. and KRONKA, SN. Morfometria de ovários de fêmeas zebu Bos taurus indicus coletados em matadouro. Acta Scientiae Veterinariae, 2006, vol. 34, n. 1, p. 65-70.

FERREIRA MBD., LOPES, BC. and DANTAS, MS. Escore do aparelho reprodutivo pré-estação de monta em novilhas Zebu aos dois anos de idade. Revista Brasileira de Reprodução Animal, 1999, vol. 23, n. 3, p. 160-162.

FONSECA, VO. Redução do período de serviço em vacas de corte. In Anais do $9^{\circ}$ Congresso Brasileiro de Reprodução Animal, 1991. Belo Horizonte: Colégio Brasileiro de Reprodução Animal, 1991. p. 1-21.

FERNANDES, CAC. and VELÁSQUEZ, LFU. Características do corpo lúteo e taxa de gestação de receptoras de embrião. Archivos de Reproduction Animal, vol. 1, p. 28-31, 1997.

GASSER, CL., BEHLKE, EJ., BURKE, CR., GRUM, DE. and MUSSARD, ML. Improvement of pregnancy rate to fixedtimeartificial insemination with progesterone treatment in anestrous pos-partum cows. Journal of Animal Science, 2003, vol. 81, suplemento 2, p. E45.

LUCY, MC., BILLINGS, HJ., BUTLER, WR., EHNIS, LR., FIELDS, MJ., KESLER, DJ., KINDER, JE., MATTOS, RC., SHORT, RE., THATCHER, WW., WETTEMAN, RP., YELICH, JV. and HAFS, HD. Efficacy of an intravaginal progesterone insert and injection of PGF2- $\alpha$ for synchronizing estrus and shortening the interval to pregnancy in postpartum beef cows, peripubertal beef heifers and dairy heifers. Journal of Animal Science, 2001, vol. 79, n. 4, p. 982-995. PMid:11325206.

LUCY, MC. Mechanisms linking nutrition and reproduction in postpartum cows. Reproduction. Supplement, 2003, vol. 61, p. 415427. PMid:14635952.

MADUREIRA, EH. and PIMENTEL, JRV. IATF como uma ferramenta para melhorar a eficiência reprodutiva. In Anais do $16^{\circ}$ Congresso Brasileiro de Reprodução Animal, 2005. Goiânia. [Palestras].

MALVEN, FV. Pathophysiology of the puerperium: definition of the problem. In Proceedings of the 10th International Congress on Animal Reproduction and Artificial Insemination, 1984. Illinois: USDA.

MCMANUS, C., SAUERESSIG, MG., FALCÃO, RA., SERRANO, G., MARCELINO, KRA. and PALUDO, GR. Componentes Reprodutivos e Produtivos no Rebanho de Corte da Embrapa Cerrados. Revista Brasileira de Zootecnia, 2002, vol. 31, n. 2, p. 648657. http://dx.doi.org/10.1590/S1516-35982002000300015

MENEGHETTI, M. and VASCONCELOS, JLM. Mês de parição, condição corporal e resposta ao protocolo de inseminação artificial em tempo fixo em vacas de corte primíparas. Arquivo Brasileiro de Medicina Veterinária e Zootecnia, 2008, vol. 60, n. 4, p. 786-793. http://dx.doi.org/10.1590/S0102-09352008000400002

MENEGHETTI, M., SÁ FILHO, OG., PERES, RFG., LAMB, GC. and VASCONCELOS, JLM. Fixed-time artificial insemination with estradiol and progesterone for Bos indicus cows I: basis for development of protocols. Theriogenology, 2009, vol. 72, n. 2, p.179-189. PMid:19344942. http://dx.doi.org/10.1016/j. theriogenology.2009.02.010 
MONTEIRO, CMR., PERRI, SHV., CARVALHAL, R. and CARVALHO, RG. Estudo morfológico comparativo dos ovários de vacas e novilhas da raça nelore (bos taurus indicus). Ars Veterinaria, 2008, vol. 24, n. 2, p. 122-126.

NASCIMENTO, AA., PINHEIRO, NL., SALES, A. and VIANA, JHM. Correlação morfométrica do ovário de fêmeas bovinas em diferentes estádios reprodutivos. Brazilian Journal of Veterinary Research and Animal Science, 2003, vol. 40, n. 2, p.126-132. http://dx.doi.org/10.1590/S1413-95962003000200006

NASCIMENTO, MGF., D'ANGELIS, FHF., NASCIMENTO, ER. and RESENDE, AO. Envolvimento de micoplasmas em vacas com distúrbios reprodutivos. Acta Scientiae Veterinariae, 2005, vol. 33, n. 2, p. 195-199.

NEVES, MM., MARQUES JUNIOR, AP., SANTANA, CV. and LIMA, FPC. Características de ovários de fêmeas zebu (Bos taurus indicus), colhidos em abatedouros. Arquivo Brasileiro de Medicina Veterinária e Zootecnia, 2002, vol. 54, n. 6, p. 651-654. http:// dx.doi.org/10.1590/S0102-09352002000600016

PALHANO, HB., JESUS, VLT., TRÉS, JE., JACOB, JCF., ALVES, PAM., FOLHADELLA, IM., RAMOS, AA. and MELLO, MRB. Reprodução em bovinos: fisiopatologia, terapêutica, manejo e biotecnologia. 2. ed. Rio de Janeiro: LF Livros, 2008. 250 p.

RIBEIRO FILHO, AL., PORTELA, APM., CHALHOUB, M., QUINTELA, AT., BITTENCOURT, RF., OLIVEIRA, JVL., GUSMAO, AL. and VALE FILHO, V. Desempenho reprodutivo de vacas zebus, submetidas à prévia classificação reprodutiva e sincronizadas com diferentes protocolos para inseminação artificial em tempo fixo. Revista Brasileira de Reprodução Animal, 2002, vol. 26, n. 3, p. 221-223.
RYAN, DP., SPOON, RA., GRIFFITH, MK. and WILLIANS, GL. Ovarian follicular recruitment, granulosa cell steroidogenic potential and grown hormone/IGF-I relationships in suckler beef cows consuming high lipid diets: effects of graded differences in body condition maintained during puerperium. Domestic Animal Endocrinology, 1994, vol. 11, n. 2, p. 161-174. http://dx.doi. org/10.1016/0739-7240(94)90024-8

TAKIUCHI, E., ALFIERI, A. F. and ALFIERI, AA. Herpesvírus bovino tipo 1: tópicos sobre a infecção e métodos de diagnóstico. Semina: Ciencias Agrárias, 2001, vol. 22, n. 2, p. 203-209. http:// dx.doi.org/10.5433/1679-0359.2001v22n2p203

VIEIRA, A., LOBATO, JFP, TORRES JUNIOR, RAA., CEZAR, IM. and CORREA, ES. Fatores Determinantes do Desempenho Reprodutivo de Vacas Nelore na Região dos Cerrados do Brasil Central. Revista Brasileira de Zootecnia, 2005, vol. 34, n. 6, suplemento, p. 2408-2416.

VIANA, JHM., FERREIRA, AM., SÁ, WF. and CAMARGO, LSA. Características morfológicas e funcionais do corpo lúteo durante o ciclo estral em vacas da raça Gir. Arquivo Brasileiro de Medicina Veterinária e Zootecnia, 1999, vol. 51, n. 3, p. 251-256. http:// dx.doi.org/10.1590/S0102-09351999000300009

WHISNANT, CS., KISER, TE. and THOMPSON, FN. Opioid inhibition of luteinizing hormone secretion during the postpartum period in suckled beef cows. Journal of Animal Science, vol. 63, n. 5, p. 1445-1448, 1986. PMid:3793650.

Received February 12, 2014 Accepted August 14, 2014 